\title{
Acute respiratory illnesses in the first 18 months of life ${ }^{1}$
}

\author{
Ilse M. López Bravo, ${ }^{2}$ Haydeé Sepúlveda, ${ }^{3}$ \& Isabel Valdés ${ }^{4}$
}

SUMMARY

To help assess the causes and frequency of acute respiratory illnesses (ARI) during the first 18 months of life in Chile, a cohort of 437 children born in good health between May 1991 and April 1992 was followed at an urban health clinic in northern Santiago. Information was obtained from medical checkups performed at the clinic, from emergency health care services, from private physicians, and from interviews with each child's mother when the child was enrolled in the study and when it was 6, 12, and 18 months old. Followup was completed for $379(87 \%)$ of the children. ARI accounted for $67 \%$ of all 3762 episodes of illness recorded for these children in the 18-month study period, 1384 (55\%) of the ARI episodes affecting the upper respiratory tract and the remaining 1144 (45\%) affecting the lower. The overall rate of ARI observed was 33 episodes per 100 child-months of observation. The incidences of upper, lower, and total ARI episodes decreased significantly in the third six months of life. A statistically significant association was found between upper ARI ( $\geq 2$ episodes) and maternal smoking ( $\geq 5$ cigarettes per day), but no significant associations were found with any of the other risk factors studied. However, lower ARI ( $\geq 2$ episodes) was significantly associated with maternal schooling ( $<8$ years), a family history of atopic allergy, and substandard housing conditions; and lower ARI ( $\geq 4$ episodes) was significantly associated with these factors and also with the existence of one or more siblings, birth in a cold season, limited breast-feeding (<4 months), and low socioeconomic status. Significant associations were found between obstructive bronchitis episodes and most of the risk factors studied (gender, siblings, season of birth, duration of breast-feeding, maternal schooling, smoking, use of polluting fuels in the home, and a family history of atopic allergy); similarly, significant associations were found between the occurrence of pneumonia and many risk factors (including siblings, season of birth, duration of breast-feeding, maternal schooling, smoking, and socioeconomic level). Overall, 42 of the study children were hospitalized during the study period for lower tract ARI, and two children died of pneumonia at home during their first 6 months of life. The rate of hospitalization fell significantly with increasing age.

1 This article has previously been published in Spanish in the Boletin de la Oficina Sanitaria Panamericana, Vol. 120, No. 5, 1996, pp. 378-388, under the title "Enfermedades respiratorias agudas en los primeros 18 meses de vida." Project 92-1091 of the National Fund for Scientific and Technological Research (FONDECYT)

2 Medical Faculty, University of Chile, School of Public Health, Santiago, Chile. Mailing address for reprint requests and other correspondence: Universidad de Chile, Facultad de Medicina, Escuela de Salud Pública, casilla 70012, correo 7, Santiago, Chile.

3 Servicio Salud Norte, Consultorio José Symon Ojeda, Santiago, Chile.

4 Roberto del Río Hospital, Respiratory Diseases Unit, Santiago, Chile.
It is only in the past 15 years that childhood respiratory illnesses have been classified as health problems. The World Health Assembly, in its resolution WHA 32/1979/REC/1 (approved in May 1979), recommended that a worldwide effort be undertaken to treat respiratory illnesses and, in particular, to reduce childhood mortality from these causes. The Declaration of the World Conference on Children, held in New York on 30 September
1990, set a goal of reducing deaths from acute respiratory infections onethird by the year 2000 in children under age 5 (1).

Although these illnesses are more frequently seen in the upper respiratory tract (2-4), those in the lower respiratory tract have considerable importance-as they frequently require costly treatments and are the primary cause of hospitalization and death between the first month and 
fourth year of life. Worldwide, every year some 4 million children under age 6 die as a result of acute respiratory illnesses (ARI) $(5,6)$.

For several reasons - the sites, intensities, and characteristics of these illnesses vary, their evolution is often brief, and their symptoms may not be noticed-they may not prompt a medical consultation. Often a child will come down with one or another several times a year. Accordingly, followup study is the most appropriate method for calculating rates of attack and number of episodes $(5,6)$.

Numerous authors have related the onset and frequency of these illnesses to social and cultural factors-including factors involving home and nonhome environments and the lifestyles of family members. Natural breastfeeding is deemed to be a factor protecting against ARI, since breast milk is rich in elements that protect the child against viral and bacterial infections. Risk factors include use of inappropriate cooking and heating fuels, poor home ventilation, low levels of maternal schooling, low family socioeconomic level, male gender, and the child's season of birth. Another important risk factor is parental smokingespecially maternal smoking, which has been associated with an increased prevalence of respiratory symptoms in infants and small children (7-14).

The study reported here estimates the frequency of ARI in the upper and lower respiratory tracts of 437 children born in Santiago, Chile, during their first 18 months of life. The study also analyzes data on a selected group of participants with respect to the influence of certain risk factors relating to the child, its mother, and the household environment upon the evolution of these illnesses.

\section{MATERIALS AND METHODS}

The 437 members of the study cohort were born between 1 May 1991 and 30 April 1992 with birth weights of 2500-4500 g. Neonates with birth weights under $2500 \mathrm{~g}$ were excluded, because such children constitute a group with distinct risk factors, such as increased mortality from pneumonia during the first year of life. Also excluded were children with congenital or perinatal diseases that might favor the subsequent onset of respiratory illness.

Cohort members with ARI were seen at the José Symon Ojeda Health Clinic of the North Metropolitan Health Service (Servicio de Salud Metropolitano Norte) from a few days after birth up to 30 October 1993, when all the participants had attained the age of 18 months. In conformity with a ministry regulation, medical checkups are given to all children eligible to receive benefits under the National Health Service System (SNSS) up to 6 years of age at the following intervals: once a month during the first six months of life, once every two months during the second six months, and once every six months thereafter. Except for the checkup at one month of age, which is done by a physician, all of these checkups are performed by professional nurses.

The study analyzed a broad spectrum of acute respiratory illnesses, ranging from acute rhinitis to pneumonia. Cases of otitis were also included because this problem often arises as a complication of ARI. For purposes of the study, ARI were classified as affecting the upper or lower respiratory tract-the upper tract encompassing the area from the nostrils to the epiglottis while the lower includes the region from the pharynx to the lungs (9).

Three lower tract ARI (bronchitis, obstructive bronchial syndrome, and the pneumonias) were analyzed separately because they were recognized as the most frequently encountered types of lower tract ARI in Chile. The diagnosis of pneumonia was confirmed in $89 \%$ of the cases by means of chest X-rays taken in the Roberto del Río Hospital, all of which were examined by a radiologist. In the remaining $11 \%$ of the diagnosed pneumonia cases initial X-rays were not taken because it was possible to make a clear diagnosis based on clinical signs and symptoms.
In $78 \%$ of the diagnosed pneumonia cases a control X-ray was taken.

ARI diagnoses were made by physicians on duty at the Roberto del Río Hospital's emergency care clinic and, occasionally, at private clinics. Mothers go to both types of clinics when their children require medical care outside normal hours (at night or on weekends). These physicians, like all those working in the area of primary care in the Chilean SNSS, had received special training in the diagnosis and treatment of ARI. The fact that one entity, the National ARI Control Program, has been responsible for this teaching activity since 1991 helped to ensure the uniformity of the diagnostic and therapeutic criteria applied in this study.

Medical checkups, as noted above, were an additional source of study data. During these checkups, nurses questioned the study children's mothers to uncover the possible existence of a respiratory condition for which no medical consultation had been sought or one that had been brought to the attention of some other health center. They also reviewed the notebooks that the mothers carried with them to record illnesses for which no care had been sought at the clinic.

In addition, at the time the child was enrolled in the study and at 6, 12, and 18 months thereafter the mothers were interviewed to obtain personal data about themselves as well as information about smoking (whether they smoked five or more cigarettes per day in the home), the family unit, the types of fuel used for cooking and heating (electricity, liquid gas, kerosene, firewood, coal), any history of atopic allergies among the study child's parents and siblings, and data needed to classify the family's socioeconomic status using Graffar's scale. This latter classification employs five variables (occupation, level of parental schooling, primary source of family income, housing quality, and neighborhood quality) to assign individuals to one of five socioeconomic strata: upper, upper-middle, middle, lower-middle, and lower (15). 
Using the accumulated data, the frequency of ARI episodes per month of life, by type of ARI, was determined. Other calculations included the average number of ARI episodes per semester, year, and type of ARI; the percentages of children experiencing different numbers of recorded episodes; and the estimated ARI rates for each 100 childmonths of observation among children whose ARI histories could have been influenced by one or another of the study variables. In comparing the various ARI rates involved, the $z$ test was employed.

\section{RESULTS}

The study began with 437 children, of whom 234 (54\%) were boys and 203 (46\%) were girls. Followup through 18 months was completed for 379 children $(87 \%), 53 \%$ of whom were boys. The 58 children lost to followup had moved to locations outside the northern sector of Santiago. Dropouts were gradual: 16 in the first semester, 29 in the second, and 13 in the third. For purposes of monthly analysis, these children were included in the study up to the last month of age during which they resided in the area of the clinic; however, for purposes of semi-annual analysis, only those children who had completed the followup for their respective semester were included. Half of the children were breast-fed through 3 months of age, at which time their diets were supplemented with formula. The average duration of breast-feeding supplemented with formula was 6 months. The weights of the study participants were evaluated by comparing weights obtained at monthly checkups through the first 4 months of age and subsequently at ages $6,8,10,12$, and 18 months with tables developed by the National Center for Health Statistics (NCHS) (16). This comparison showed that the children's weight increases were adequate.

The average maternal age at birth was 25.5 years, within a range of 15-44 years (Table 1). Some $87 \%$ had completed their eight years of basic educa- tion; of these, $42 \%$ had completed their four years of mid-level education and some had studied at higher levels. Only 15 mothers had less than five years of schooling.

Three out of every four mothers were living in a stable union with the child's father. With regard to the mothers' employment status, this was found to vary with the study children's age. While only $15 \%$ of the mothers worked outside the home at the time the child was born, after 18 months this figure had risen to $23 \%$. In $65 \%$ of the homes, one or more family members smoked at the time the child was born. Some $21 \%$ of the mothers smoked at that time, with that percentage increasing to $31 \%$ in subsequent months.

Some $54 \%$ of the children's parents (mother and father, or just the mother if she was unmarried) identified themselves as allegados (individuals who lived with family members or friends without contributing money to the home due to their inability to pay).

With regard to the quality of the home's construction, $85 \%$ of the children lived in solidly built dwellings while the remainder lived in houses built of lightweight materials with unreinforced wooden walls, piecedtogether floors, and roofs made with pieces of metal or other material generally not tied into the home's structure. In almost all the homes (97\%), gas was used for cooking, while for heating purposes most homes (81\%) used fuels classified as pollutants (kerosene, firewood, coal). While all the study families possessed a radio, $85 \%$ possessed a television, and $45 \%$ possessed a refrigerator, only $30 \%$ had hot water. The socioeconomic status of $82 \%$ of the children was classified as lower-middle or lower; only $18 \%$ were classified at level 3, the middle level in Graffar's classification.

Some $27 \%$ of the family members (grandparents, parents, or siblings) of the children studied reported a history of one or more of the following conditions: asthma, atopic allergy, chronic bronchitis, or nocturnal coughing.

The morbidity analysis produced the following results: Over the 18- month followup period, a total of 3762 episodes of illnesses of varying etiology were recorded, of which $67 \%$ (2528) involved ARI. Of the latter, 55\% (1384) were upper tract infections, while $45 \%$ (1144) affected the lower tract. (While in some cases both types occurred virtually simultaneously or sequentially in the same patient, for purposes of the study each type was counted separately.) Of the lower tract infections, $45 \%$ (511) were classified as bronchitis, $40 \%$ (462) as obstructive bronchitis, and $15 \%$ (171) as pneumonia. The average number of episodes of upper and lower ARI was 5.1 during the first year of life and 1.4 in the third semester.

Upper ARI were observed in 347 children, the average being 4 episodes per affected child in the 18-month followup period. The number of episodes per child ranged from a low of 1 in 51 children (Table 2) to a high of 14 in three children. The average number of episodes annually per affected child was 3.5 , while the average number occurring in the third semester was 1.9. Four or more episodes of upper ARI were recorded for $45 \%$ of the children, while $8 \%$ elicited no diagnosis of upper ARI during the study period.

Lower ARI affected 293 of the study children, producing an average of 3.9 episodes per affected child in the 18month followup period. The number of episodes varied from 1 (in 82 children) to 20 (in two children). The annual average was 3.6 episodes per affected child, while the average per affected child in the third semester was 2.1. No lower tract ARI were recorded for 86 of the children during the 18-month study period, while 4 or more episodes were recorded for 117. Similar numbers of study children (55 and 53) were found to have 7 or more episodes of upper and lower ARI, respectively (Table 2).

The rates of ARI per 100 childmonths of observation in each semester were calculated for all ARI taken together, as well as separately for upper and lower tract ARI. The overall rate for the 18-month study period was 33 ARI per 100 child-months of 
TABLE 1. Certain characteristics of the mothers of the 437 children included in the study cohort

\begin{tabular}{llrr}
\hline \multicolumn{1}{c}{ Characteristic } & \multicolumn{1}{c}{ Category } & No. & $\%$ \\
\hline Age (years) & $15-19$ & 82 & 18.8 \\
& $20-29$ & 244 & 55.8 \\
& $30-44$ & 111 & 25.4 \\
Schooling (years) & $\leq 5$ & 15 & 3.4 \\
& $6-7$ & 42 & 9.6 \\
& $\geq 8$ & 380 & 87.0 \\
Marital status & Married & 249 & 57.0 \\
& In union & 86 & 19.7 \\
& Single & 89 & 20.4 \\
& Divorced & 13 & 3.0 \\
Were working (of mothers & When the child was born & 66 & 15.0 \\
not lost to followup) & After 6 months & 69 & 16.3 \\
& After 12 months & 82 & 21.0 \\
& After 18 months & 87 & 23.0 \\
Were smoking & & & \\
$\geq 5$ cigarettes per day & When the child was born & 109 & 21.2 \\
& After 6 months & 121 & 25.9 \\
& After 12 months & 119 & 30.9 \\
& After 18 months & 31.4 \\
\hline
\end{tabular}

observation. However, as Figure 1 shows, the rates of both upper and lower ARI that were recorded diminished notably, especially in the third semester, with increasing age.

Of the 293 study children with lower tract ARI, 74\% had at least one case of bronchitis during the study period, $66 \%$ had obstructive bronchitis, and $32 \%$ had pneumonia. Table 3 shows the frequency distribution of lower

TABLE 2. The numbers of upper tract and lower tract ARI episodes experienced over the course of the first 18 months of life by each of the 379 study cohort children for whom complete data were gathered

\begin{tabular}{crrrrr}
\hline \multirow{2}{*}{$\begin{array}{c}\text { Number } \\
\text { of episodes }\end{array}$} & \multicolumn{2}{c}{ Upper ARI } & & \multicolumn{2}{c}{ Lower ARI } \\
\cline { 6 - 6 } & No. & $\%$ & & No. & $\%$ \\
\hline 0 & 32 & 8.4 & & 86 & 22.7 \\
1 & 51 & 13.5 & & 82 & 21.6 \\
$2-3$ & 125 & 33.0 & & 94 & 24.8 \\
$4-6$ & 116 & 30.6 & & 64 & 16.9 \\
$\geq 7$ & 55 & 14.5 & & 53 & 14.0 \\
Total & 379 & 100.0 & & 379 & 100.0 \\
\hline
\end{tabular}

tract ARI diagnosed during the 18month followup period, while Table 4 shows the average number of episodes of each type of illness. As Table 3 indicates, during this period 207 (55\%) of the study children contracted a serious ARI (obstructive bronchitis, pneumonia, or both).

As Figure 2 shows, the monthly incidences of both upper and lower tract ARI tended to decline over the course

TABLE 3. The different types of lower tract ARI diagnosed in the 379 study cohort children with complete data, showing the numbers and percentages of children experiencing each type of ailment during the first 18 months of life

\begin{tabular}{lrr}
\hline \multicolumn{1}{c}{ ARI } & No. & $\%$ \\
\hline $\begin{array}{l}\text { Pneumonia and obstructive } \\
\text { bronchial syndrome }\end{array}$ & 80 & 21.1 \\
Pneumonia & 13 & 3.4 \\
Obstructive bronchial $^{\text {syndrome }}{ }^{\mathrm{a}}$ & 114 & 30.1 \\
Bronchitis $_{\text {No lower ARI }}$ & 86 & 22.7 \\
$\quad$ Total & 86 & 22.7 \\
& 379 & 100.0 \\
\hline a Includes children who also had bronchitis.
\end{tabular}

FIGURE 1. Rates of upper, lower, and total ARI per 100 child-months among children in the study cohort

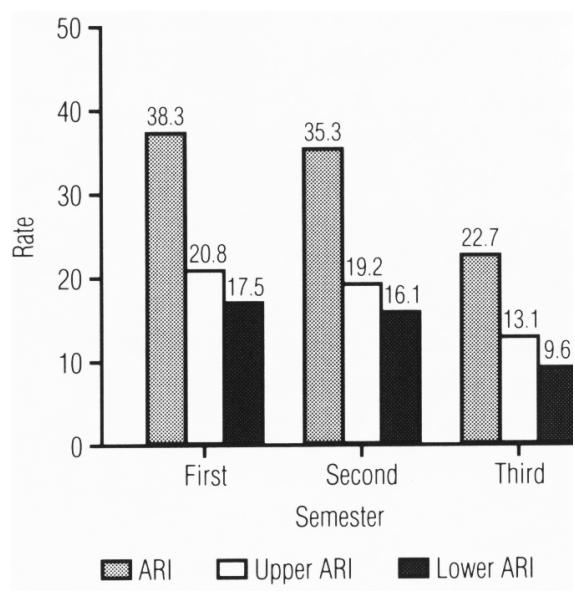

of the study period. However, as indicated in the figure, during the first two months of life the percentage of children exhibiting respiratory problems was considerably less than it was over the next few months.

Table 5 compares the rates of upper and lower ARI experienced by children who were or were not exposed to various possible child-related, motherrelated, and environment-related risk factors. Regarding upper tract ARI, the only statistically significant difference found was between children living in homes where the family members smoked a combined total of at least five cigarettes per day in the house, as compared to children living in homes where this was not the case. In contrast, significantly higher percentages of children born to mothers with less than eight years of schooling, born into families with histories of atopic allergy, or experiencing poor living conditions (no refrigerator or hot water, walls made of unreinforced wood) were found to have experienced two or more lower ARI episodes; and all of these groups plus those with one or more siblings, those born in cold seasons, those breast-fed less than 4 months, and those with low 
TABLE 4. The numbers of children with complete data experiencing different kinds of ARI episodes, the numbers of episodes recorded, and the average number of recorded episodes per affected child.

\begin{tabular}{|c|c|c|c|}
\hline ARI & $\begin{array}{l}\text { Average } \\
\text { episodes per } \\
\text { affected } \\
\text { child }\end{array}$ & $\begin{array}{c}\text { Episodes } \\
\text { (No.) }\end{array}$ & $\begin{array}{c}\text { Children } \\
\text { (No.) }\end{array}$ \\
\hline Upper tract & 4.0 & 1384 & 347 \\
\hline Lower tract & 3.9 & 1144 & 293 \\
\hline Bronchitis & 2.4 & 511 & 217 \\
\hline $\begin{array}{l}\text { Obstructive } \\
\text { bronchial }\end{array}$ & & & \\
\hline syndrome & 2.4 & 462 & 194 \\
\hline Pneumonia & 1.8 & 171 & 93 \\
\hline
\end{tabular}

socioeconomic status were significantly more likely to have experienced four or more lower ARI episodes $(P<0.05)$.

Similar analysis with regard to obstructive bronchitis and pneumonia (Table 6) revealed significant associations $(P<0.05)$ between two or more episodes of obstructive bronchitis and being of the male gender, having one or more siblings, being born in a cold season, having been breast-fed for fewer than four months, having family members who smoked a combined total of five or more cigarettes per day in the home, living in a home where polluting fuels were used, or being born into a family with a history of atopic allergy. The risk of having an episode of pneumonia was associated significantly with most of the variables studied with the exception of gender, exclusive breast-feeding, maternal age, and use of polluting fuel.

Over the course of the 18-month observation period 62 hospitalizations were recorded, of which $50(81 \%)$ were caused by lower tract ARI-20 classed as pneumonia (as the sole diagnosis) and 30 classed as obstructive bronchitis, there being a total of 30 cases that in fact involved a combination of pneumonia and obstructive bronchitis. The remaining hospitalized cases $(19 \%)$ were attributed to nonrespiratory illness. The hospitalization rate for pneumonia was 30 hospitalizations
FIGURE 2. Monthly incidences of upper and lower tract ARI during each of the first 18 months of life among children included in the study cohort. The data charted were calculated by taking the number of children with episodes in any month and dividing by the total number of children completing that month of observation.

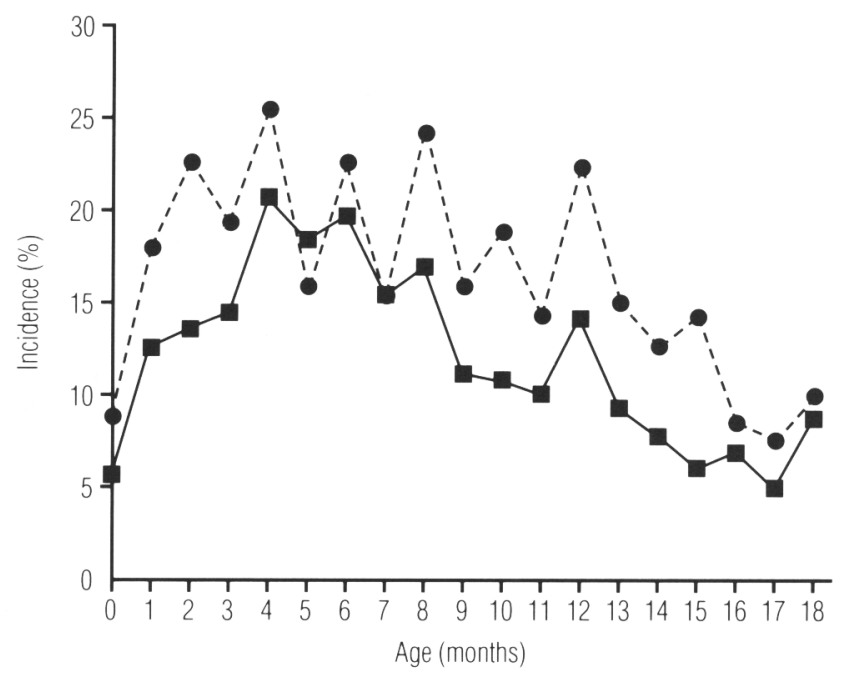

per 100 episodes, this rate varying from 39 in the first semester to 18 in the third. The 50 recorded hospitalizations involved 42 children, 6 (14\%) of whom were hospitalized on two or three occasions.

Factors significantly increasing the risk of hospitalization for pneumonia (Table 7) included being of the male gender, having one or more siblings, having a birth-weight of 25002999 g (versus $\geq 3000 \mathrm{~g}$ ), being exclusively breast-fed less than 4 months, being breast-fed less than 4 months, being born to a mother with less than 8 years of schooling, and having a low socioeconomic status. As the table shows, the hospitalization rates were higher for children born to older mothers ( $\geq 20$ years) and for those in homes where family members smoked at least five cigarettes per day, but these differences were not statistically significant. Overall, the risk of hospitalization declined significantly with age-from $64 \%$ in the first semester to $22 \%$ in the second and $14 \%$ in the third. The average duration of breast-feeding among children who were hospitalized was 2 months, significantly less than the average for the whole group (4 months). It should also be noted that during the first trimester of the cohort followup two ARI deaths (from pneumonia) occurring at home were recorded.

\section{DISCUSSION}

It should be emphasized that the study results reflect selection criteria, and that the children selected were representative of a lower to lowermiddle socioeconomic sector benefiting from a government health system that guaranteed periodic medical checkups and care for illness. As noted previously, children with low birthweights $(<2500 \mathrm{~g})$ or with congenital or perinatal diseases predisposing them to ARI were excluded from the study.

The results obtained justify the concern expressed by health organizations with regard to ARI. During the first 18 months of life, $77 \%$ of the children studied had one or more episodes of lower tract ARI-a very high percent- 
TABLE 5. Percentages of study children with complete data, grouped according to their exposure to various possible risk factors, who experienced upper ARI ( $\geq 2$ episodes) or lower ARI ( $\geq 2$ and $\geq 4$ episodes) in their first 18 months of life.

\begin{tabular}{|c|c|c|c|c|c|c|c|}
\hline \multirow[b]{3}{*}{ Variables } & \multirow[b]{3}{*}{ Category } & \multirow{2}{*}{\multicolumn{2}{|c|}{$\begin{array}{c}\text { Upper ARI } \\
\text { (2 or more } \\
\text { episodes) }\end{array}$}} & \multicolumn{4}{|c|}{ Lower ARI } \\
\hline & & & & \multicolumn{2}{|c|}{$\begin{array}{l}2 \text { or more } \\
\text { episodes }\end{array}$} & \multicolumn{2}{|c|}{$\begin{array}{l}4 \text { or more } \\
\text { episodes }\end{array}$} \\
\hline & & $\%$ & $P$ & $\%$ & $P$ & $\%$ & $P$ \\
\hline \multicolumn{8}{|l|}{ Child-related } \\
\hline Sex & $\begin{array}{l}\text { Boy } \\
\text { Girl }\end{array}$ & $\begin{array}{l}82.5 \\
78.2\end{array}$ & 0.1539 & $\begin{array}{l}58.6 \\
56.3\end{array}$ & 0.3264 & $\begin{array}{l}34.5 \\
29.1\end{array}$ & 0.1492 \\
\hline Siblings & $\begin{array}{l}\text { No } \\
\text { Yes }\end{array}$ & $\begin{array}{l}81.6 \\
79.1\end{array}$ & 0.1949 & $\begin{array}{l}52.6 \\
61.5\end{array}$ & 0.0559 & $\begin{array}{l}25.9 \\
36.8\end{array}$ & 0.0202 \\
\hline Season at birth & $\begin{array}{l}\text { Cold } \\
\text { Warm }\end{array}$ & $\begin{array}{l}81.6 \\
75.0\end{array}$ & 0.0749 & $\begin{array}{l}56.4 \\
60.0\end{array}$ & 0.2912 & $\begin{array}{l}35.2 \\
20.0\end{array}$ & 0.0064 \\
\hline $\begin{array}{l}\text { Duration of } \\
\text { exclusive } \\
\text { breast-feeding } \\
\text { (months) }\end{array}$ & $\begin{array}{l}<4 \\
\geq 4\end{array}$ & $\begin{array}{l}82.6 \\
78.9\end{array}$ & 0.2005 & $\begin{array}{l}58.9 \\
55.6\end{array}$ & 0.2743 & $\begin{array}{l}45.8 \\
48.3\end{array}$ & 0.3446 \\
\hline $\begin{array}{l}\text { Duration of total } \\
\text { breast-feeding } \\
\text { (months) }\end{array}$ & $\begin{array}{l}<4 \\
\geq 4\end{array}$ & $\begin{array}{l}80.5 \\
80.5\end{array}$ & & $\begin{array}{l}58.9 \\
53.7\end{array}$ & 0.2061 & $\begin{array}{l}35.3 \\
22.0\end{array}$ & 0.0129 \\
\hline \multicolumn{8}{|l|}{ Maternal } \\
\hline Age (years) & $\begin{array}{l}<20 \\
\geq 20\end{array}$ & $\begin{array}{l}87.1 \\
78.7\end{array}$ & 0.0668 & $\begin{array}{l}64.5 \\
55.5\end{array}$ & 0.0985 & $\begin{array}{l}35.5 \\
30.8\end{array}$ & 0.2389 \\
\hline $\begin{array}{l}\text { Schooling } \\
\text { (years) }\end{array}$ & $\begin{array}{l}<8 \\
\geq 8\end{array}$ & $\begin{array}{l}80.5 \\
80.0\end{array}$ & & $\begin{array}{l}70.7 \\
55.3\end{array}$ & 0.0314 & $\begin{array}{l}46.3 \\
29.4\end{array}$ & 0.0146 \\
\hline \multicolumn{8}{|l|}{ Environmental } \\
\hline $\begin{array}{l}\text { Consumption of } \\
\text { cigarettes ( } \geq 5 / \text { day) }\end{array}$ & $\begin{array}{l}\text { Yes } \\
\text { No }\end{array}$ & $\begin{array}{l}77.3 \\
87.7\end{array}$ & 0.0392 & $\begin{array}{l}63.0 \\
54.5\end{array}$ & 0.1379 & $\begin{array}{l}42.9 \\
33.6\end{array}$ & 0.1401 \\
\hline Fuel & $\begin{array}{l}\text { Polluting } \\
\text { Nonpolluting }\end{array}$ & $\begin{array}{l}80.5 \\
80.0\end{array}$ & & $\begin{array}{l}61.1 \\
55.8\end{array}$ & 0.1539 & $\begin{array}{l}26.7 \\
33.3\end{array}$ & 0.1271 \\
\hline $\begin{array}{l}\text { Socioeconomic } \\
\text { level }\end{array}$ & $\begin{array}{l}\text { Middle and } \\
\text { lower-middle } \\
\text { Low }\end{array}$ & $\begin{array}{l}81.2 \\
75.6\end{array}$ & 0.2005 & $\begin{array}{l}56.7 \\
63.4\end{array}$ & 0.2090 & $\begin{array}{l}29.6 \\
43.9\end{array}$ & 0.0329 \\
\hline $\begin{array}{l}\text { History of } \\
\text { atopic allergy }\end{array}$ & $\begin{array}{l}\text { No } \\
\text { Yes }\end{array}$ & & & $\begin{array}{l}53.7 \\
69.2\end{array}$ & 0.008 & $\begin{array}{l}28.0 \\
43.6\end{array}$ & 0.0064 \\
\hline $\begin{array}{l}\text { Household } \\
\text { conditions }\end{array}$ & $\begin{array}{l}\text { Acceptable } \\
\text { Poor }\end{array}$ & $\begin{array}{l}79.4 \\
81.0\end{array}$ & 0.3859 & $\begin{array}{l}45.7 \\
62.3\end{array}$ & 0.0045 & $\begin{array}{l}19.8 \\
35.4\end{array}$ & 0.0044 \\
\hline
\end{tabular}

age compared to the $30 \%$ reported by the Tucson study $(7,8)$.

More than half of the recorded lower tract ARI episodes involved obstructive bronchitis or pneumonia, illnesses that may require hospitalization or special care and that can prove fatal. The percentage of hospitalizations $(12 \%)$ was high when compared to the $1 \%$ reported in the Tucson study $(7,8)$.

It can be stated with considerable certainty that there was no duplication in the recording of the reported ARI the first year of life in Chile. In 1993, for example, they accounted for $14.9 \%$ of all deaths in this age group; and while other general causes of death accounted for higher percentages of total fatalities, these causes were in fact large collections of diagnoses such as "perinatal afflictions" $(29.8 \%)$ "traumas and poisonings" (29.3\%), and "congenital anomalies" (25.3\%). In our study, pneumonias caused the only two deaths recorded. Overall, these circumstances affirm a need to make all actions undertaken against ARI intersectoral in nature and to direct them toward overall improvements in child health by stressing ARI prevention.

It is also essential to educate the public about the need to seek medical care when necessary, and to establish health teams with the resources required to adequately meet the demands for care.

The numbers of children with upper and lower tract ARI decreased with increasing age; however, the average number of episodes did not drop significantly, indicating that the risk factors for ARI persisted throughout the entire age interval studied.

The average number of annual episodes per child (incidence of ARI during the study period) was lower than the figures reported in other published studies. On the other hand, the percentage of children ill during the study period (prevalence of ARI during the period) was significantly higher (7-11). One possible cause of these circumstances was the health education activities undertaken by the National ARI Control Program carried out under the auspices of Chile's Ministry of Health. Among other things, these activities involve having physicians and nurses deliver or distribute educational materials to mothers when the latter seek care for respiratory illnesses as well as during normal health checkups performed at SNSS facilities-including the clinic where the current study was performed. Another possible cause was the long duration of certain episodes of obstructive bronchitis (>40 days). 
TABLE 6. Percentages of study children with complete data, grouped according to their exposure to various possible risk factors, who experienced $\geq 2$ episodes of obstructive bronchitis or $\geq 1$ episode of pneumonia in their first 12 months of life.

\begin{tabular}{|c|c|c|c|c|c|}
\hline \multirow[b]{2}{*}{ Variables } & \multirow[b]{2}{*}{ Category } & \multicolumn{2}{|c|}{$\begin{array}{l}\text { Obstructive } \\
\text { bronchitis } \\
\text { ( } \geq 2 \text { episodes) }\end{array}$} & \multicolumn{2}{|c|}{$\begin{array}{l}\text { Pneumonia } \\
\text { ( } \geq 1 \text { episode) }\end{array}$} \\
\hline & & $\%$ & $P$ & $\%$ & $P$ \\
\hline \multicolumn{6}{|l|}{ Child-related } \\
\hline Sex & $\begin{array}{l}\text { Boy } \\
\text { Girl }\end{array}$ & $\begin{array}{l}48.4 \\
37.8\end{array}$ & 0.0183 & $\begin{array}{l}21.9 \\
16.3\end{array}$ & 0.0838 \\
\hline Siblings & $\begin{array}{l}\text { Yes } \\
\text { No }\end{array}$ & $\begin{array}{l}53.9 \\
38.9\end{array}$ & 0.0084 & $\begin{array}{l}28.8 \\
14.9\end{array}$ & 0.0014 \\
\hline Season at birth & $\begin{array}{l}\text { Cold } \\
\text { Warm }\end{array}$ & $\begin{array}{l}47.8 \\
39.5\end{array}$ & 0.0465 & $\begin{array}{l}23.4 \\
15.4\end{array}$ & 0.0228 \\
\hline $\begin{array}{l}\text { Duration of } \\
\text { exclusive } \\
\text { breast-feeding } \\
\text { (months) }\end{array}$ & $\begin{array}{l}<4 \\
\geq 4\end{array}$ & $\begin{array}{l}45.3 \\
42.1\end{array}$ & 0.2643 & $\begin{array}{l}21.9 \\
16.9\end{array}$ & 0.1056 \\
\hline $\begin{array}{l}\text { Duration of total } \\
\text { breast-feeding } \\
\text { (months) }\end{array}$ & $\begin{array}{l}<4 \\
\geq 4\end{array}$ & $\begin{array}{l}51.6 \\
41.1\end{array}$ & 0.0436 & $\begin{array}{l}27.4 \\
16.8\end{array}$ & 0.0119 \\
\hline \multicolumn{6}{|l|}{ Maternal } \\
\hline Age (years) & $\begin{array}{l}<20 \\
\geq 20\end{array}$ & $\begin{array}{l}51.3 \\
61.5\end{array}$ & 0.0643 & $\begin{array}{l}14.9 \\
17.8\end{array}$ & 0.2946 \\
\hline $\begin{array}{l}\text { Schooling } \\
\text { (years) }\end{array}$ & $\begin{array}{l}<8 \\
\geq 8\end{array}$ & $\begin{array}{l}53.4 \\
42.0\end{array}$ & 0.0537 & $\begin{array}{l}39.6 \\
15.8\end{array}$ & 0.0001 \\
\hline $\begin{array}{l}\text { Environmental } \\
\text { Consumption of } \\
\text { cigarettes }(\geq 5 / \text { day })\end{array}$ & $\begin{array}{l}\text { No } \\
\text { Yes }\end{array}$ & $\begin{array}{l}40.8 \\
54.1\end{array}$ & 0.0089 & $\begin{array}{l}12.8 \\
27.9\end{array}$ & $<0.0001$ \\
\hline Fuel & $\begin{array}{l}\text { Polluting } \\
\text { Nonpolluting }\end{array}$ & $\begin{array}{l}47.3 \\
34.2\end{array}$ & 0.0099 & $\begin{array}{l}20.6 \\
15.7\end{array}$ & 0.1379 \\
\hline $\begin{array}{l}\text { Socioeconomic } \\
\text { level }\end{array}$ & $\begin{array}{l}\text { Middle and lower-middle } \\
\text { Low }\end{array}$ & $\begin{array}{l}42.6 \\
49.0\end{array}$ & 0.1922 & $\begin{array}{l}17.3 \\
30.2\end{array}$ & 0.0132 \\
\hline $\begin{array}{l}\text { History of } \\
\text { atopic allergy }\end{array}$ & $\begin{array}{l}\text { Yes } \\
\text { No }\end{array}$ & $\begin{array}{l}53.0 \\
36.8\end{array}$ & 0.0068 & $\begin{array}{l}\mathrm{a} \\
\mathrm{a}\end{array}$ & \\
\hline
\end{tabular}

In addition, the study children tended not to be exposed to certain risk factors. They were initially selected to have a birth weight of at least 2500 grams, they were not malnourished, only $18.8 \%$ of their mothers were teenagers, and all but $3.4 \%$ of the mothers had at least 6 years of formal education $(7,8)$. They also benefitted from various factors considered favorable-most were cared for personally by their mothers rather than going to day care centers, most received regu- larly scheduled medical checkups, and most of their mothers did not work outside the home. For these reasons, it is appropriate to attribute the high frequency of lower tract ARI recorded to other factors possibly relating to an unfavorable economic situation (including inappropriate housing, domestic pollution caused by the use of inappropriate fuel for heating, cigarette smoke, crowding, etc.) whose contributions have been demonstrated in other countries.
It should also be noted that Santiago is one of the world's most polluted cities, and so it would be enlightening to compare the results obtained in this study with those obtained by similar studies of Chilean children living in relatively unpolluted regions of the country (9-19). There is also a need to continue following the study cohort, in view of the frequency of lower tract ARI observed, in order to explore the future repercussions of these ailments. 
TABLE 7. Percentages of study children with complete data, grouped according to their exposure to various possible risk factors, who were hospitalized for pneumonia in their first 18 months of life

\begin{tabular}{|c|c|c|c|}
\hline Variables & Category & $\begin{array}{c}\% \text { hospitalized } \\
\text { for } \\
\text { pneumonia }\end{array}$ & $P$ \\
\hline $\begin{array}{l}\text { Child-related } \\
\text { Sex }\end{array}$ & $\begin{array}{l}\text { Boy } \\
\text { Girl }\end{array}$ & $\begin{array}{r}12.5 \\
6.9\end{array}$ & 0.0207 \\
\hline Siblings & $\begin{array}{l}\text { No } \\
\text { Yes }\end{array}$ & $\begin{array}{r}6.4 \\
14.1\end{array}$ & 0.0071 \\
\hline Birth-weight (g) & $\begin{array}{l}2500-2999 \\
\geq 3000\end{array}$ & $\begin{array}{r}17.1 \\
9.0\end{array}$ & 0.0174 \\
\hline $\begin{array}{l}\text { Duration of } \\
\text { exclusive } \\
\text { breast-feeding } \\
\text { (months) }\end{array}$ & $\begin{array}{l}<4 \\
\geq 4\end{array}$ & $\begin{array}{r}14.6 \\
6.7\end{array}$ & 0.0057 \\
\hline $\begin{array}{l}\text { Duration of mixed } \\
\text { breast and bottle } \\
\text { feeding (months) }\end{array}$ & $\begin{array}{l}<4 \\
\geq 4\end{array}$ & $\begin{array}{r}17.5 \\
8.3\end{array}$ & 0.0048 \\
\hline $\begin{array}{l}\text { Maternal } \\
\text { Age (years) }\end{array}$ & $\begin{array}{l}<20 \\
\geq 20\end{array}$ & $\begin{array}{r}8.1 \\
11.3\end{array}$ & 0.0548 \\
\hline $\begin{array}{l}\text { Schooling } \\
\text { (years) }\end{array}$ & $\begin{array}{l}<8 \\
\geq 8\end{array}$ & $\begin{array}{r}19.2 \\
9.4\end{array}$ & 0.0166 \\
\hline $\begin{array}{l}\text { Environmental } \\
\text { Consumption of } \\
\text { cigarettes ( } \geq 5 / \text { day })\end{array}$ & $\begin{array}{l}\text { Yes } \\
\text { No }\end{array}$ & $\begin{array}{r}11.9 \\
7.1\end{array}$ & 0.0901 \\
\hline $\begin{array}{l}\text { Socioeconomic } \\
\text { level }\end{array}$ & $\begin{array}{l}\text { Middle and lower-middle } \\
\text { Low }\end{array}$ & $\begin{array}{l}12.5 \\
27.3\end{array}$ & 0.0001 \\
\hline
\end{tabular}

\section{REFERENCES}

1. Organización Panamericana de la Salud, Organización Mundial de la Salud. Informe Programa IRA de la OMS. Washington, DC: OPS/OMS; 1990:1-2.

2. Chile, Ministerio de Salud, Secretaría Regional Ministerial, Asesoría de Estadística. Indicadores de atención de salud: región metropolitana, anuario 1992. Santiago: Ministerio de Salud; 1992:25-27.

3. Kaempffer AM, Medina E. Hospitalización infantil en Chile, situación actual y perspectivas. Rev Chil Pediatr 1992;63:110-117.

4. López I, Sepúlveda H. Egresos de menores de 15 años en área consultorio J Symon Ojeda, Hospital R del Río 1988 a 1990. Rev Pediatr (Santiago) 1991;34:88-92.

5. Pío A. Acute respiratory infections in children in developing countries: an international point of view. Pediatr Infect Dis 1986;5:179-183.

6. Organización Panamericana de la Salud. Control de casos de infecciones respiratorias agudas en los niños: estudios de intervención, informe de reunión en Ginebra 19-21 abril 1989. Washington, DC: OPS; 1989. (Document HPM/IRA/ 89.1).

7. Taussig LM, Wright AL, Morgan WJ, Harrison HR, Ray CG, Group Health Medical Associates. The Tucson children's respiratory study: I. design and implementation of a prospective study of acute and chronic respiratory illness in children. Am J Epidemiol 1989;129:1219-1231.

8. Wright AL, Taussig LM, Harrison HR, Holberg CJ. The Tucson children's respiratory study: II. lower respiratory illness in the first year of life 1987. Am J Epidemiol 1989;129:12321246.

9. Benguigui $Y$. Infecciones respiratorias agudas. In: Meneghello J, ed. Volume III: diálogos en pediatría. Santiago, Chile: Publicaciones Técnicas Mediterráneo; 1990:11-26.

10. Woodward A, Douglas RM, Graham NMH, Miles $\mathrm{H}$. Acute respiratory illness in Adelaide: child breast feeding modifies the effect of pas- sive smoking. J Epidemiol Community Health 1990;44:224-230.

11. Phelan PD, Landau LI, Olinsky A. Respiratory illness in children. 2nd ed. Oxford: Blackwell Scientific Publications; 1982:32-38.

12. Chenker MB, Samet JM, Speizer FE. Risk factors for childhood respiratory diseases: the effects of home factors and home environmental exposures. Am Rev Respir Dis 1983;128:1083-1143.

13. Lebowitz MD. The relationship of social environmental factors to the prevalence of obstructive lung diseases and other chronic conditions. J Chronic Dis 1977;121:3-10.

14. Tager IB, Weiss ST, Muñoz A, Rosner B, Speizer FE. Longitudinal study of the effects of maternal smoking on pulmonary function in children. N Engl J Med 1983;309:699-703.

15. Valenzuela J, Díaz E, Klaggs B. Empleo de un nuevo método de clasificación social. Cuad Med Soc (Santiago) 1976;17:14-22. 
16. López I, Tapia M, Valdés I, Sepúlveda H. Diagnósticos del estado nutricional en el primer año de vida. Rev Pediatr (Santiago) 1993;36:122-126.

17. Aranda C, Belmar R, Bello S, Múñoz M, Sheppard D, Oyarzún M. El problema de la contaminación atmosférica en la ciudad de Santiago. Enf Resp Cir Torac 1990;6:69-78.
18. Meneghello J. Investigación pediátrica en atención primaria de salud: una tarea de todos. Pediatr al Día 1994;1:5-26.

19. Chile, Ministerio de Salud. Normas de atención primaria del niño y del adolescente: Servicio de Salud Metropolitano Norte. Santiago: Ediciones Caupolicán; 1989:133-161.
Manuscript received on 19 January 1995. Accepted for publication in Spanish in the Boletín de la Oficina Sanitaria Panamericana (following revision) on 8 February 1996. Accepted for publication in English in the Revista Panamericana de Salud Pública/Pan American Journal of Public Health on 2 April 1996.

RESUMEN Para conocer las causas y frecuencia de las enfermedades respiratorias agudas (ERA) durante los primeros 18 meses de vida en una población chilena, se siguió, en un consultorio urbano del norte de Santiago, a una cohorte de 437 niños nacidos sanos entre mayo de 1991 y abril de 1992. La información se obtuvo de los controles médicos realizados en el consultorio, del servicio de urgencia y de médicos particulares, así como de entrevistas a las madres al incorporar a los niños en el estudio y a los 6, 12 y 18 meses del seguimiento. Completaron el seguimiento 379 niños (87\%). Las ERA constituyeron $67 \%$ de los 3762 episodios de enfermedad registrados en los niños durante el período de 18 meses, 1384 (55\%) de las vías altas y 1144 (45\%) de las bajas. La tasa total de ERA fue de 33 episodios por 100 meses-niño de observación. Las incidencias de ERA alta y baja, y el total de episodios descendieron significativamente durante los terceros 6 meses de edad. Se encontró una asociación estadísticamente significativa entre la ERA alta ( $\geq 2$ episodios) y la escolaridad de la madre $(<8$ años), antecedentes familiares de atopia y viviendas en malas condiciones. La ERA baja ( $\geq 4$ episodios) se asoció significativamente con esos factores y además con la existencia de uno o más hermanos, haber nacido en un mes frío, haber recibido lactancia materna menos de 4 meses y pertenecer a un bajo estrato socioeconómico. Los episodios de bronquitis obstructiva se asociaron significativamente con la mayor parte de los factores de riesgo (sexo, hermanos, mes de nacimiento, duración de la lactancia, escolaridad materna, familiares que fumaban, uso de combustibles contaminantes en el hogar y antecedentes familiares de atopia). De modo similar, hubo asociaciones significativas entre la neumonía y muchos factores de riesgo (hermanos, mes de nacimiento, duración de la lactancia, escolaridad materna, familiares que fumaban y condición socioeconómica). En general, 42 niños fueron hospitalizados durante el período de estudio por ERA bajas y 2 niños murieron de neumonía en el hogar antes de cumplir los 6 meses. La tasa de hospitalizaciones disminuyó significativamente a medida que aumentó la edad. 